\title{
CALGARY'S SPECIALIZED DOMESTIC VIOLENCE COURT: AN EVALUATION OF A UNIQUE MODEL
}

\author{
LESLIE M. TUTTY AND JENNIFER KOSHAN*
}

Specialized domestic violence courts are a recent innovation in the justice system's response to domestic violence, with the objective of more effectively addressing domestic violence by jointly holding offenders more accountable and improving safety for victims. Calgary's court, developed in 2001, began as a unique model focusing on DV specialization in the docket court, speeding entry into the justice system, and treatment for low risk offenders. In 2005, DV specialization was expanded to the trial court. This article presents data on over 6,407 cases from a tenyear period, 1998 to 2008, capturing the development of the model over the years from baseline, specialized docket to specialized trial courts. The results cover the characteristics of the accused and victims, criminal history, and court outcomes. It also presents a summary of the results of interviews with justice and community stakeholders and men mandated to treatment. Implications for the justice system and for jurisdictions considering developing a specialized DV court approach are presented.
Les tribunaux spécialisés en violence conjugale (VC) sont une récente innovation de la réponse $d u$ système de justice à la violence conjugale. Leur raison d'être consiste à aborder plus efficacement la violence conjugale en tenant les agresseurs plus responsables et en améliorant la sécurité des victimes. Le tribunal de Calgary, développé en 2001, a un modèle unique axé sur la VC comme spécialisation de rôle, ce qui accélère l'entrée dans le système de justice et le traitement des délinquants à faible risque. En 2005, la spécialisation en $C V$ a été élargie au tribunal de première instance. Cet article contient les données de plus de 6407 accusés sur une période de 10 ans, de 1998 à 2008, et reflète l'évolution du modèle au fil des années, du produit de base, puis les rôles spécialisés et ensuite les tribunaux spécialisés. Les résultats couvrent les caractéristiques des accusés et des victimes, les antécédents criminels et les décisions des tribunaux. L'auteur donne aussi un sommaire des résultats des entrevues avec des intervenants du milieu de la justice et de la communauté ainsi que les hommes qui ont été obligés à suivre un traitement. Les implications pour le système de justice et les ressorts qui envisagent le développement d'un tribunal spécialisé en VC y sont présentées.

\section{TABLE OF CONTENTS}

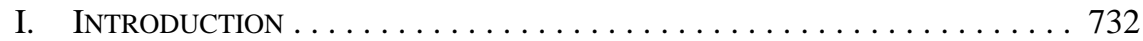

II. Calgary’s Specialized Domestic Violence Court Model . . . . . 735

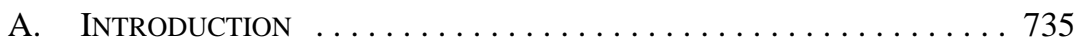

Leslie M Tutty, PhD, Professor Emeritus, Faculty of Social Work, University of Calgary; Jennifer Koshan, BSc, LLB, LLM, Associate Professor, Faculty of Law, University of Calgary.

This article is based on Leslie Tutty et al, Evaluation of the Calgary Specialized Domestic Violence Trial Court \& Monitoring the First Appearance Court: Final Report (Calgary: RESOLVE Alberta, 2011), online: RESOLVE Alberta <http://www.academia.edu/1596000/Evaluation_of_the_Calgary_ Specialized_Domestic_Violence_Trial_Court_and_Monitoring_the_First_Appearance_Court_Final_ Report_to_National_Crime_Prevention_and_the_Ālberta_Law_Foundation>. The evaluation was funded by the National Crime Prevention Centre of Public Safety Canada and the Alberta Law Foundation, and we gratefully acknowledge their financial support. The Evaluation Team consisted of Sheena Cunningham (Crown Prosecutor's Office Calgary), Shawne Young (Chief Probation Officer, Calgary District Probation), Robbie Babins-Wagner (CEO, Calgary Counselling Centre), Carolyn Goard, Arla Liska and Cynthia Wild (YWCA of Calgary Sheriff King Home), Dr. Sue Ludwig and Aggie KingSmith (Alberta Mental Health Board), Leslie Buckle (Senior Evaluation Analyst, National Crime Prevention Centre), and Kevin McNichol (Executive Director, HomeFront). Thank you to research assistants Swartika Nair, Amanda Dietrich, Joëlle Robichaud, Kristin Jones, Mallory Faul, Lindsay Merrifield, Kathleen Ganley, and Jocey Bonneycastle, who collected the data, which was a complex and time-consuming job. A special thank you to the staff of the Crown's office and HomeFront, both the domestic court caseworkers and the administrative support, for facilitating access to the data. Thank you also to the anonymous reviewers of this article for their helpful comments. 
B. The Specialized Domestic Violence First Appearance

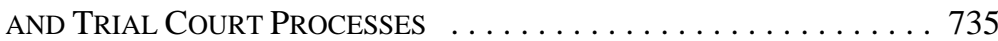

III. COURT TRACKING DATA ANALYSIS . . . . . . . . . . . . . . . . . . . . . . . . 737

A. CHARACTERISTICS OF THE ACCUSED AND ViCTIMS . . . . . . . . . . 738

B. CRIMINAL BACKGROUND AND INCIDENT CHARACTERISTICS . . . . . . 741

C. Resolutions in THE DOCKET AND TRIAL COURTS . . . . . . . . . . . 745

D. EstimAtes of NEW CHARGES/RECIDIVISM . . . . . . . . . . . . . 749

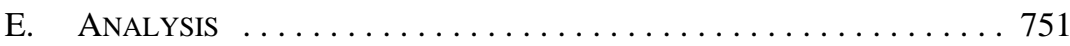

F. QUALITATIVE DATA ......................... 752

IV. CONCLUSIONS ......................... 753

\section{INTRODUCTION}

The serious nature of intimate partner violence and the harm to women and their children has been acknowledged in numerous studies. ${ }^{1}$ In a "substantial proportion" of domestic violence cases in Canada and the United States, the criminal justice system now intervenes, which is the result of broad policy changes across North America over the past three decades at all levels of the justice system, including the police, prosecutions, courts, and corrections. ${ }^{2}$ There have also been critiques of the justice system's recent response to domestic violence, ${ }^{3}$ which have led to changes to policy and practice purported to improve victim safety and offender accountability. One of these changes has been the development of specialized criminal domestic violence (DV) courts. ${ }^{4}$

Beginning with the development of the first Canadian DV court in Winnipeg in 1991, specialized DV courts have become increasingly present across Canada. ${ }^{5}$ Specialized DV

See e.g. Statistics Canada, Family Violence in Canada: A Statistical Profile 2009 (Ottawa: Minister of Industry, 2009), online: Statistics Canada <http://www.statcan.gc.ca/pub/85-224-x/85-224-x200 9000eng.pdf $>$; Leslie M Tutty \& Carolyn Goard, eds, Reclaiming Self: Issues and Resources for Women Abused by Intimate Partners (Halifax: Fernwood, 2002) [Tutty \& Goard, Reclaiming Self]. Leslie M Tutty, Jane Ursel \& Fiona Douglas, "Specialized Domestic Violence Courts: A Comparison of Models," in Jane Ursel, Leslie M Tutty \& Janice LeMaistre, eds, What's Law Got To Do With It? The Law, Specialized Courts and Domestic Violence in Canada (Toronto: Cormorant Press, 2008) 69 at 69. See also Betsy Tsai, "The Trend Toward Specialized Domestic Violence Courts: Improvements on an Effective Innovation” (2000) 68:4 Fordham L Rev 1285; Jane Ursel, “'His Sentence is My Freedom”: Processing Domestic Violence Cases in the Winnipeg Family Violence Court” in Tutty \& Goard, Reclaiming Self, ibid at 43.

These critiques include the identification of problems with the under- and over-enforcement of criminal laws, often against members of marginalized groups. For a discussion of critiques in Canada and the US, see e.g. Donna Coker, "Crime Control and Feminist Law Reform in Domestic Violence Law: A Critical Review” (2001) 4:2 Buff Crim L Rev 801 at 803; Dawn H Currie, "Battered Women and The State: From The Failure of Theory to a Theory of Failure" (1990) 1:2 The Journal of Human Justice 77; Deborah Epstein, "Effective Intervention in Domestic Violence Cases: Rethinking the Roles of Prosecutors, Judges, and the Court System” (1999) 11:3 Yale JL \& Feminism 3; Emily J Sack, “Battered Women and the State: The Struggle for the Future of Domestic Violence Policy" (2004) 6 Wis L Rev 1657; Frances Salvaggio, "K-Court: The Feminist Pursuit of an Interdisciplinary Approach to Domestic Violence” (2002) 8 Appeal 6; Elizabeth M Schneider, Battered Women \& Feminist Lawmaking (New Haven, CT: Yale University Press, 2000); Tsai, ibid.

4 In the US, some specialized DV courts deal with civil protection orders and family law matters, including those that are integrated and hear civil, criminal, and family matters. See Emily Sack, Creating a Domestic Violence Court: Guidelines and Best Practices (San Francisco: Family Violence Prevention Fund, 2002) at 24-29. In Canada, all specialized DV courts are criminal. However, Toronto recently introduced an integrated DV court.

5 See Tutty, Ursel \& Douglas, “Specialized Domestic Violence Courts: A Comparison of Models,” supra note 2 at $80-81$. 
courts are a form of problem-solving court with some unique features. ${ }^{6}$ Two basic principles ground most specialized DV courts: early intervention for low risk offenders and vigorous prosecution for serious repeat offenders. Early intervention typically allows accused persons who admit responsibility to be ordered into batterer treatment and similar programs soon after the offence. Vigorous prosecution, in contrast, often involves specialized police units and Crown attorneys working with offenders and victims to ensure "the strongest prosecution effort possible" for repeat or serious offenders. ${ }^{7}$

The term "specialized court" entails more than the court system. Most involve community treatment agencies coordinating with the efforts of (sometimes) specialized police units, Crown prosecutors, victim advocates, and probation officers. ${ }^{8}$ Some DV courts also have dedicated judges. However, in Canada, most use rotating judges who are educated about the dynamics of domestic violence. ${ }^{9}$

There are different models of specialization with different processes. Some DV courts involve judges in the monitoring of probation orders while others use probation officers. ${ }^{10}$ Some courts rely less on the victim testifying by, for example, acquiring photographs of the victim's injuries or tapes from 911 phone calls. ${ }^{11}$ Others develop programs to support and advocate for victims in the hope that they will testify. ${ }^{12}$ Two American studies found that victims who utilized advocacy programs and protection orders were much more likely to testify or see their cases through to completion in court. ${ }^{13}$

To date, few evaluations have assessed the extent to which specialized DV court initiatives make a difference. Exceptions in Canada include evaluations of the specialized

For discussions of DV courts as problem-solving courts, see Michael C Dorf \& Jeffrey A Fagan, "Community Courts and Community Justice: Problem-Solving Courts: From Innovation to Institutionalization” (2003) 40:4 Am Crim L Rev 1501; Judith S Kaye \& Susan K Knipps, “Judicial Responses to Domestic Violence: The Case for a Problem Solving Approach” (1999) 27:1 W St U L Rev 1; Samantha Moore, Two Decades of Specialized Domestic Violence Courts: A Review of the Literature (New York: Center for Court Innovation, 2009) at 1; Melissa Labriola et al, A National Portrait of Domestic Violence Courts (New York: Center for Court Innovation, 2011) at ix; Donald E Shelton, The Current State of Domestic Violence Courts in the United States, 2007 (Williamsburg, VA: National Center for State Courts White Paper Series, 2007) at 7; Tsai, supra note 2 at 1294-96; Robert V Wolf, Liberty Aldrich \& Samantha Moore, Planning a Domestic Violence Court: The New York State Experience (New York: Center for Court Innovation, 2004) at 5. Tutty, Ursel \& Douglas, “Specialized Domestic Violence Courts: A Comparison of Models,” supra note 2 at 76

Julia C Babcock \& Ramalina Steiner, "The Relationship Between Treatment, Incarceration, and Recidivism of Battering: A Program Evaluation of Seattle's Coordinated Community Response to Domestic Violence" (1999) 13:1 Journal of Family Psychology 46; Melanie F Shepard, "Evaluating a Coordinated Community Response,” in Melanie F Shepard \& Ellen L Pence, eds, Coordinating Community Responses to Domestic Violence: Lessons from Duluth and Beyond (Thousand Oaks, CA: Sage, 1999) 169; Tutty, Ursel \& Douglas, ibid at 75.

$9 \quad$ Labriola et al, supra note 6 at 1.

10 Tutty, Ursel \& Douglas, "Specialized Domestic Violence Courts: A Comparison of Models," supra note 2 at $74-75$.

$11 \quad$ Myrna Dawson \& Ronit Dinovitzer, "Victim Cooperation and the Prosecution of Domestic Violence in a Specialized Court" (2001) 18:3 Justice Quarterly 593.

12 Irene Hoffart \& Michelle Clarke, HomeFront Evaluation: Final Report (Calgary: HomeFront Evaluation Committee, 2004), online: HomeFront <http://www.homefrontcalgary.com/assests/files/HomeFront\%20 Evaluation\%20Final\%20Report.pdf $>$.

13 Arlene N Weisz, Richard M Tolman \& Larry Bennett, “An Ecological Study of Nonresidential Services for Battered Women Within a Comprehensive Community Protocol for Domestic Violence" (1998) 13:4 Journal of Family Violence 395; Amy P Barasch \& Victoria L Lutz, “Innovations in the Legal System’s Response to Domestic Violence: Thinking Outside the Box for the Silent Majority of Battered Women" in Albert R Roberts, ed, Handbook of Domestic Violence Intervention Strategies: Policies, Programs, and Legal Remedies (New York: Oxford University Press, 2002) 173. 
DV court in Winnipeg, ${ }^{14}$ and courts in Toronto, ${ }^{15}$ Calgary, ${ }^{16}$ the Yukon, ${ }^{17}$ and New Brunswick. ${ }^{18}$ Evaluations of American specialized DV courts include courts in South Carolina, ${ }^{19}$ Massachusetts, ${ }^{20}$ Manhattan, ${ }^{21}$ and Brooklyn. ${ }^{22}$ Each of these evaluations focuses on one or two sites, sometimes comparing the criminal justice outcomes to the period before the court became specialized. In general, the most common results are increased conviction rates and reduced recidivism. ${ }^{23}$

This article presents results from an evaluation of Calgary's specialized DV court model, assessing whether it is meeting its goals of improving the quality and processes of the criminal justice response to domestic violence. ${ }^{24}$ The objectives of this research were to examine the outcomes of cases in the specialized courts (docket and trial) compared to baseline data (which measure domestic violence case outcomes before specialization), to capture the opinions of key community and justice stakeholders about the impact of the courts, and to interview a number of accused who were mandated to batterer intervention programs after the DV specializations took place in order to understand the impact of the courts from their perspective.

With respect to methodology, we collected data from Crown files from both the specialized domestic violence first appearance and trial courts in Calgary for an eight year period (from 2000 until 2008), supplementing already-collected data for a previous evaluation by Irene Hoffart and Michelle Clarke. ${ }^{25}$ In total, including the baseline, data was

Ursel, “His Sentence is My Freedom,” supra note 2; Jane Ursel \& Christine Hagyard, “The Winnipeg Family Violence Court,” in Ursel, Tutty \& LeMaistre, What's Law Got To Do With It?, supra note 2 at 95.

15 Myrna Dawson \& Ronit Dinovitzer, “Specialized Justice: From Prosecution to Sentencing in a Toronto Domestic Violence Court,” in Ursel, Tutty \& LeMaistre, What's Law Got To Do With It?, ibid at 120; Susan Eley, "Changing Practices: The Specialised Domestic Violence Court Process" (2005) 44:2 The Howard Journal 113.

$16 \quad$ Hoffart \& Clarke, supra note 12; Leslie M Tutty, Kevin McNichol \& Janie Christensen, “Calgary’s HomeFront Specialized Domestic Violence Court,” in Ursel, Tutty \& LeMaistre, What's Law Got To Do With It?, ibid at 152.

17 Joseph P Hornick et al, “The Yukon's Domestic Violence Treatment Option: An Evaluation,” in Ursel, Tutty \& LeMaistre, What's Law Got To Do With It?, ibid at 172.

18 Carmen Gill \& Lanette Ruff, Moncton Provincial Court-Domestic Violence Pilot Project: A Comparative Study (Fredericton: Muriel McQueen Fergusson Centre for Family Violence Research, 2010), online: Government of New Brunswick <http://www.gnb.ca/0012/Womens-Issues/Domestic ViolenceCourt/ 2010-03ViolencePilotProject.pdf>.

19 Angela R Gover, John M MacDonald \& Geoffrey P Alpert, “Combating Domestic Violence: Findings from an Evaluation of a Local Domestic Violence Court” (2003) 3:1 Criminology and Public Policy 109; Angela R Gover, Eve M Brank \& John M MacDonald, “A Specialized Domestic Violence Court in South Carolina: An Example of Procedural Justice for Victims and Defendants” (2007) 13:6 Violence Against Women 603.

20 Anat Maytal, “Specialized Domestic Violence Courts: Are They Worth the Trouble in Massachusetts?” (2008) 18:1 BU Pub Int LJ 197.

21 Richard R Peterson, The Impact of Manhattan's Specialized Domestic Violence Court: Final Report (New York: New York City Criminal Justice Agency, 2004), online: Criminal Justice Agency <http://www.cjareports.org/reports/manhat46.pdf>.

22 Lisa Newmark et al, Specialized Felony Domestic Violence Courts: Lessons on Implementation and Impacts from the Kings County Experience (Washington, DC: US Department of Justice, 2001), online: National Criminal Justice Reference Service <http://www.ncjrs.gov/pdffiles1/nij/grants/199723.pdf > .

23 See e.g. Lois A Ventura \& Gabrielle Davis, "Domestic Violence: Court Case Conviction and Recidivism” (2005) 11:2 Violence Against Women 255.

24 Leslie Tutty et al, Evaluation of the Calgary Specialized Domestic Violence Trial Court \& Monitoring the First Appearance Court: Final Report (Calgary: RESOLVE Alberta, 2011) at 71-72, online: RESOLVE Alberta <http://www.academia.edu/1596000/Evaluation_of_the_Calgary_Specialized_ Domestic_Violence_Trial_Court_and_Monitoring_the_First_Appearance_Court_Final_Report_to_ National_Crime_Prevention_and_the_Alberta_Law_Foundation>. Hoffart \& Clarke, supra note 12. 
available for a ten-year period for 6,407 domestic violence cases. We also conducted interviews with 31 stakeholders from the justice and legal community, counseling, treatment, advocacy, and other community agencies, and with 37 men who had been mandated by the court to attend batterer treatment programs.

\section{Calgary’s Specialized Domestic Violence Court Model}

\section{A. INTRODUCTION}

Calgary's DV court model developed in early 2000 with the input of key players from criminal justice institutions such as police services, Crown prosecutor offices, probation, Legal Aid, and the defence bar, as well as community agencies that offer batterer intervention programs and support, shelter, and advocacy for victims. The model was innovative, with the initial emphasis on a specialized domestic violence docket court at the Provincial Court level. The specialized docket court had the aim of speeding up the process for those charged with domestic abuse offences to allow low risk offenders to take responsibility for their actions and speed their entry into treatment. Cases proceeding to trial were heard in regular criminal court.

This approach was thought to better safeguard victims because their partners were mandated to treatment much earlier and prevent repercussions to victims who, if the case proceeded to trial, might be required to testify. Also, the safety and wishes of the victims are taken into consideration by the court team early on in the process while the assault is still fresh in their minds and they are not influenced by the accused to the same extent as they might be later on. According to Hoffart and Clarke, after three years, the specialized domestic violence docket court had expedited the justice system process with lower recidivism rates. $^{26}$

Following these early successes, the justice community in Calgary developed a specialized domestic violence trial court that opened in March of 2005 to more adequately address high risk, repeat offenders. The two specialized courts work in concert, yet address different needs.

\section{B. The SPECialized Domestic Violence First APPEARANCE and Trial Court Processes}

The judiciary was initially specialized in the DV court, though now all Calgary Provincial Court (Criminal Division) judges rotate through the specialized court. The court team consists of specialized representatives from the Calgary Police Services Domestic Conflict Unit, the Crown, probation services, and court caseworkers from HomeFront (the non-profit agency that supports the court process). The court team meets for "pre-court conferences" before court is in session each day and again during breaks. The team reviews the particulars of each case with the defence or duty counsel and determines which course they will pursue. 
At this time, information about the victim's wishes is conveyed by the HomeFront court caseworkers and new information from any team member can be introduced. Furthermore, members have the opportunity to request additional information they may need from other members before meeting again, such as letters from victims asking that no contact orders be lifted or expressing that the victim is fearful and pursuing a restraining or protection order, address and employment updates from probation and police officers, verification of treatment attendance and compliance, the accused's criminal record and past history with probation, or any changes in the perceived level of risk for the accused or the victim. The goal is to provide the court with as much information as possible so that it can make appropriate decisions in a timely manner.

Docket, or first appearance court, is the first opportunity for an accused to enter a plea. However, many other steps can occur before a plea is accepted, including adjournments to allow an accused to make an application for legal aid coverage and to retain a lawyer, to allow information or paperwork to catch up to the court, or until an interpreter can be made available. Some adjournments are made for tactical reasons, such as when other charges or court decisions are pending for an accused. Duty counsel, the defence, or the Crown may request that the case be heard at a later time because they do not yet have all the necessary information.

A unique feature of the specialized DV court in Calgary is the role of HomeFront court caseworkers, who provide essential services related to victim support. Each morning, they review the police 24-hour incident reports to collect new offence information and begin contacting the victims in those cases within a day of the police laying charges. Further, they review each case before every court appearance and ensure that victims' wishes are up to date and that victims are aware of the status of the case against their partners. The workers typically inquire about a past history of abuse, current relationship status with the accused, perceived level of danger, and the victims' wishes with respect to court outcomes. This information is supplemented with standardized risk assessment tools such as the Danger Assessment, ${ }^{27}$ which is often vital in guiding the decisions of the court and supplementing and balancing information provided by other sources. Safety planning for victims is undertaken by connecting the victim to community or legal resources, including counseling programs, immigrant serving agencies, shelters, and the Court Preparation and Restraining Order programs at Calgary Legal Guidance. The court caseworkers also keep victims updated about the progress of their partner or ex-partner's case, including information such as the date of the next court appearance and the plea entered. Court caseworkers, by necessity, may also liaise with other agency representatives in Calgary, including Child and Family Services.

With low risk cases more quickly addressed in the specialized docket court, the Crown prosecutor's office has more capacity to deal with the often more complex cases that proceed to trial. According to an evaluation team member, initially there were not enough prosecutors in the specialized domestic violence unit to cover all the trials, but that issue has been

27 Jacquelyn C Campbell, Daniel W Webster \& Nancy Glass, “The Danger Assessment: Validation of a Lethality Risk Assessment Instrument for Intimate Partner Femicide” (2009) 24:4 Journal of Interpersonal Violence 653. 
resolved. The judiciary were committed to scheduling domestic trials expeditiously with the original goal being to have all matters set down for trial in three months. While that goal was not always met, the turnaround time tended to be much less than for other matters that went to trial.

Where the court team deems it appropriate and the accused accepts responsibility for his actions, the charges are withdrawn, and the accused enters into a peace bond to abide by conditions to keep the peace, report to a probation officer, attend and complete mandated treatment for domestic violence or substance abuse, or attend a parenting course. ${ }^{28}$ Often peace bonds include conditions of no contact with the victim, geographic restrictions, and abstinence from drugs and alcohol. In all cases involving peace bonds, the accused are required to acknowledge before the court the substance of their actions that led to the criminal charges and express a willingness to participate in domestic violence or other appropriate treatment programs. The accused are typically given a short time frame - on average, four days - to contact their probation officers and treatment agencies to ensure that they access treatment resources more quickly than in non-specialized courts. Probation orders are then monitored by probation officers rather than the judiciary.

The bulk of accused persons seen by the court and mandated to treatment are referred to the Calgary Counselling Centre, YWCA Sheriff King Home, and the Alberta Alcohol and Drug Abuse Commission, with a smaller percentage going to Forensic Assessment Outpatient Services at the Peter Lougheed Hospital. Additional referrals are also given, depending on case circumstances, to immigrant-serving agencies or first-language counsellors that can address cultural and settlement issues, First Nations counselling or culturally-based services, mental health resources, brain injury resources, and others.

\section{Court Tracking Data Analysis}

This analysis compares data from three time periods: baseline (before 2000 — primarily 1998 to 2000: 1,663 cases), the introduction of the specialized docket court only (2001-2004: 3,319 cases), and introduction of the specialized trial court or "full" DV court (2005-2008: 1,425 cases) for a total of 6,407 cases. The analyses address the characteristics of the accused and victims, criminal background of the accused and characteristics of the incident reported to the police, resolutions and dispositions from the docket and trial courts, and recidivism.

Other jurisdictions, such as the specialized DV process in Airdrie, handle low risk offenders differently by urging them to plead guilty (Leslie Tutty, Comparison of Calgary and Airdrie's Specialized Domestic Violence Court Cases, Calgary, AB: RESOLVE Alberta, 2010). The accused may be given a conditional discharge if they fulfill certain requirements such as attending batterer or substance abuse treatment. After a year, if the conditions are met, the discharge becomes absolute. The differences in these two processes are both practical and philosophical. The process in Calgary provides an incentive to take responsibility for assaultive actions with the charges being withdrawn conditional on the accused agreeing to treatment, effectively sidestepping a criminal conviction. The Airdrie process similarly demands that the accused take responsibility by pleading guilty, but rewards compliance to the conditions with an absolute discharge. Philosophically, Airdrie's process demands a more public and serious acceptance of guilt. Calgary's procedure of not asking the accused to plead guilty has been a long-standing criticism given that the accused only verbally state their guilt, without official acceptance of responsibility. However, no differences in recidivism were found in the study. 


\section{A. Characteristics OF THE ACCUSED AND Victims}

One would not necessarily expect differences in the characteristics of the accused and victims over time, unless there were significant changes in the community or specialized processes were targeted to particular groups, which is not a factor in the current DV court model in Calgary. Therefore, only significant differences are highlighted in this section. While the bulk of cases handled in the DV specialized courts are spousal assaults, cases with respect to different forms of abuse (such as child abuse and elder abuse) are also dealt with by the courts. When looking at the proportions of spousal assaults compared to other assaults (see Table 1), no differences were identified across court developmental phases.

Table 1: Spousal versus No Spousal by Court Development Phase

\begin{tabular}{|l|l|l|l|l|}
\hline Type of Assault & Baseline & DV Docket & Full DV Court & Totals \\
\hline Spousal assault & $1321(79.9 \%)$ & $2601(79.8 \%)$ & $1148(82.4 \%)$ & $5070(80.4 \%)$ \\
\hline Assaults other than spousal & $332(20.1 \%)$ & $660(20.2 \%)$ & $245(17.6 \%)$ & $1237(19.6 \%)$ \\
\hline Totals & 1653 & 3261 & 1393 & 6307 \\
\hline Pearson's chi-square $=4.7, \mathrm{p}=.10$ (not significant) $^{29}$ \\
\hline
\end{tabular}

With respect to the sex of the accused (see Table 2), the majority of those charged were men, while women represented less than 15 percent of the total. As can be seen in Table 3, the victims were primarily women. There were no differences in the sex of the accused or victims across the court developmental phases.

Table 2: Sex of the Accused by Court Development Phase

\begin{tabular}{|l|l|l|l|l|}
\hline Sex & Baseline & DV Docket & Full DV Court & Total \\
\hline Men & $1440(86.6 \%)$ & $2792(84.3 \%)$ & $1226(86.0 \%)$ & $5458(85.3 \%)$ \\
\hline Women & $222(13.4 \%)$ & $521(15.7 \%)$ & $199(14.0 \%)$ & $942(14.7 \%)$ \\
\hline Totals & 1662 & 3313 & 1425 & 6400 \\
\hline \multicolumn{2}{|l|}{ Pearson's chi-square $=5.8, \mathrm{p}=.06$ (not significant) } \\
\hline
\end{tabular}

Table 3: Sex of the Victim by Court Development Phase

\begin{tabular}{|l|l|l|l|l|}
\hline Sex & Baseline & DV Docket & Full DV Court & Total \\
\hline Men & $301(18.2 \%)$ & $607(18.4 \%)$ & $265(18.7 \%)$ & $1173(18.4 \%)$ \\
\hline Women & $1355(81.8 \%)$ & $2684(81.6 \%)$ & $1151(81.3 \%)$ & $5190(81.6 \%)$ \\
\hline Totals & 1656 & 3291 & 1416 & 6363 \\
\hline \multicolumn{2}{|l}{ Pearson's chi-square $=.15, \mathrm{p}=.93$ (not significant) } \\
\hline
\end{tabular}

29 When variables are categorical (i.e. male or female) a statistical test called Pearson's chi-square is used to test whether there are differences in this variable across the three court developmental phases (another categorical variable). A significant chi-square has the probability of being an error in less than 5 of 100 cases. However, given the large sample in the research, significant chi-square tests are common. To compensate for this and to adopt a higher standard of success, an additional statistical test, Cramer's V, was used when the chi-square was significant. Under .10 is a negligible association; .11 to .20 is "small" but still important; .21 to .40 is moderate (Louis M Rea \& Richard A Parker, Designing and Conducting Survey Research: A Comprehensive Guide (San Francisco: Jossey-Bass, 1992) at 203). 
Details about the relationship between the accused and the victim are presented in Table 4.

Table 4: Accused Victim Relationships by Court Developmental Phase

\begin{tabular}{|l|l|l|l|l|}
\hline Type of Relationship & Baseline & DV Docket & $\begin{array}{l}\text { Full DV } \\
\text { Court }\end{array}$ & Total \\
\hline Married heterosexual couples & $363(22.4 \%)$ & $746(23.2 \%)$ & $323(23.4 \%)$ & $1432(23.0 \%)$ \\
\hline Common law husband or wife & $455(28.1 \%)$ & $878(27.3 \%)$ & $392(28.4 \%)$ & $1725(27.7 \%)$ \\
\hline Boyfriend/Girlfriend & $141(8.7 \%)$ & $334(10.4 \%)$ & $169(12.2 \%)$ & $644(10.4 \%)$ \\
\hline Ex-Spouse/Legally Separated/Divorced & $50(3.1 \%)$ & $143(4.4 \%)$ & $52(3.8 \%)$ & $245(3.9 \%)$ \\
\hline Ex-Common law partners & $106(6.5 \%)$ & $147(4.6 \%)$ & $64(4.6 \%)$ & $317(5.1 \%)$ \\
\hline Ex-Boyfriend/Girlfriend & $150(9.3 \%)$ & $260(8.1 \%)$ & $120(8.7 \%)$ & $530(8.5 \%)$ \\
\hline Other family members & $154(9.5 \%)$ & $158(4.9 \%)$ & $61(4.4 \%)$ & $373(6.0 \%)$ \\
\hline Child/Parent/Step-parent etc. & $170(10.5 \%)$ & $305(9.5 \%)$ & $140(10.1 \%)$ & $615(9.9 \%)$ \\
\hline Same sex/ex-same sex relationship & $6(0.4 \%)$ & $17(0.5 \%)$ & $8(0.6 \%)$ & $31(0.5 \%)$ \\
\hline Other non-family (caregiver, friend) & $25(1.5 \%)$ & $228(7.1 \%)$ & $53(3.8 \%)$ & $306(4.9 \%)$ \\
\hline Total & 1620 & 3216 & 1382 & 6218 \\
\hline
\end{tabular}

Because the table regarding the victim and accused relationship is so complex and therefore difficult to interpret, the data was collapsed (as can be seen in Table 5). In terms of the intimate couple relationships, almost two-thirds were still in the relationships, whereas one-sixth of the assault incidents involved ex-partners. There were no significant changes over court phases for this data.

Table 5: Accused Victim Relationship (Collapsed) by Court Developmental Phase

\begin{tabular}{|l|l|l|l|l|}
\hline Type of Relationship & Baseline & DV Docket & $\begin{array}{l}\text { Full DV } \\
\text { Court }\end{array}$ & Total \\
\hline Current partners & $965(65.6 \%)$ & $1970(61.3 \%)$ & $891(64.5 \%)$ & $3826(61.5 \%)$ \\
\hline Ex-Partners & $306(18.9 \%)$ & $555(17.3 \%)$ & $237(17.1 \%)$ & $1098(17.7 \%)$ \\
\hline Other family members (child/parent) & $324(20 \%)$ & $483(15 \%)$ & $203(14.7 \%)$ & $1009(16.2 \%)$ \\
\hline Other non-family (caregiver, friend) & $25(1.5 \%)$ & $209(6.5 \%)$ & $51(3.7 \%)$ & $285(4.6 \%)$ \\
\hline Total & 1620 & 3216 & 1382 & 6218 \\
\hline Pearson's chi-square $=85, p<.000 ;$ Cramer's V =.08 (a negligible effect) & & \\
\hline
\end{tabular}

The information regarding the racial backgrounds of the accused across the court developmental phases can be seen in Table 6 . The almost 22 percent of accused from ethnic minority groups is slightly higher than the estimate for Calgary from the 2002 Canada Census (21 percent). The proportion of accuseds from an Aboriginal background (approximately 11 percent overall) was higher than the approximately 3 percent among the city of Calgary population, indicating that they were over-represented in the justice system with respect to spousal abuse. This may be explained in part by the over-representation of 
Aboriginal peoples in the criminal justice system more broadly and the high rates of domestic violence reported by Aboriginal women. ${ }^{30}$

Table 6: Racial Background of Accused Collapsed by Court Developmental Phase

\begin{tabular}{|l|l|l|l|l|}
\hline Racial Group & Baseline & DV Docket & Full DV Court & Total \\
\hline White/European origins & $381(70.6 \%)$ & $2135(67.8 \%)$ & $849(64.8 \%)$ & $3365(67.3 \%)$ \\
\hline Aboriginal & $65(12.0 \%)$ & $352(11.2 \%)$ & $132(10.1 \%)$ & $549(11.0 \%)$ \\
\hline Ethnic minority & $94(17.4 \%)$ & $661(21.0 \%)$ & $329(25.1 \%)$ & $1084(21.7 \%)$ \\
\hline Total & 540 & 3148 & 1310 & 4998 \\
\hline Pearson's chi-square $=76.1, \mathrm{p}$ & $=.000$; Cramer's V $=.09$ (a negligible effect) \\
\hline
\end{tabular}

Table 7 shows negligible differences in the racial background of victims (collapsed over court phases). Aboriginal victims are also over-represented in these statistics relative to their proportion in the population.

Table 7: Racial Background of Victim Collapsed by Court Developmental Process

\begin{tabular}{|l|l|l|l|l|}
\hline Racial Group & Baseline & DV Docket & Full DV Court & Total \\
\hline White/European origins & $1162(75.6 \%)$ & $1463(68.0 \%)$ & $764(66.4 \%)$ & $3389(70.0 \%)$ \\
\hline Aboriginal & $139(9.0 \%)$ & $253(11.8 \%)$ & $120(10.4 \%)$ & $512(10.6 \%)$ \\
\hline Ethnic minority & $237(15.4 \%)$ & $437(20.3 \%)$ & $266(23.1 \%)$ & $940(19.4 \%)$ \\
\hline Total & 1538 & 2153 & 1150 & 4841 \\
\hline Pearson's chi-square $=38.2, \mathrm{p}=.000, \mathrm{df}=4$; Cramer's V =.063 (a negligible effect) \\
\hline
\end{tabular}

With respect to current employment status (see Table 8), slightly over two-thirds of the accused were employed in some manner (67.1 percent were employed full- or part-time), and a little over one-quarter were unemployed or on welfare (26.5 percent). The "other” category includes students and retirees. There were no significant changes over time in this data.

Table 8: Employment of Accused by Court Development Phase

\begin{tabular}{|l|l|l|l|l|}
\hline Employment Status & Baseline & DV Docket & $\begin{array}{l}\text { Full DV } \\
\text { Court }\end{array}$ & Total \\
\hline Employed & $703(68.3 \%)$ & $1506(63.6 \%)$ & $883(73.2 \%)$ & $3092(67.1 \%)$ \\
\hline Unemployed/Welfare/Disability & $259(25.2 \%)$ & $709(29.9 \%)$ & $253(21 \%)$ & $1221(26.5 \%)$ \\
\hline Other & $67(6.7 \%)$ & $154(6.5 \%)$ & $71(5.95 \%)$ & $292(6.3 \%)$ \\
\hline Total & 1029 & 2369 & 1207 & 4605 \\
\hline Pearson's chi-square $=36.9, \mathrm{p}<.000, \mathrm{df}=8$; Cramer's V =.06 (a negligible effect) & \\
\hline
\end{tabular}

30 For discussions of this issue in the context of Winnipeg's DV court, where there is also overrepresentation of Aboriginal men, see Ursel \& Hagyard, supra note 14 at 105; Elizabeth Comack \& Gillian Balfour, The Power to Criminalize: Violence, Inequality and the Law (Halifax: Fernwood, 2004) at $155-56$. 
Whether or not the accused or victims had minor children residing with them the time of the incident is of interest because of concerns about the possible negative impacts on children of being exposed to intimate partner violence. ${ }^{31}$ As can be seen in Table 9, of the 4,100 victims and accused for whom this information is available, 56.4 percent had minor children, 41.3 percent had no children and 2.3 percent had no minor children. Because information on this variable was difficult to obtain for the baseline period, the number is too small to warrant conducting a statistical analysis.

Table 9: Number of Minor Children by Court Development Phase

\begin{tabular}{|l|l|l|l|l|}
\hline Number of Children & Baseline & DV Docket & $\begin{array}{l}\text { Full DV } \\
\text { Court }\end{array}$ & Total \\
\hline No minor children & $3(1.4 \%)$ & $50(1.9 \%)$ & $43(3.6 \%)$ & $96(2.3 \%)$ \\
\hline One minor child & $78(37.1 \%)$ & $662(24.6 \%)$ & $335(27.9 \%)$ & $1075(26.2 \%)$ \\
\hline Two or three minor children & $48(22.8 \%)$ & $701(26.1 \%)$ & $327(27.2 \%)$ & $1076(26.3 \%)$ \\
\hline Four or more minor children & $5(2.4 \%)$ & $105(3.9 \%)$ & $50(4.2 \%)$ & $160(3.9 \%)$ \\
\hline No children & $76(36.2 \%)$ & $1172(43.6 \%)$ & $445(37.1 \%)$ & $1693(41.3 \%)$ \\
\hline Total & 210 & 2690 & 1200 & 4100 \\
\hline
\end{tabular}

In summary, there were no important distinctions between the characteristics of the accused and victims across the three court developmental phases. This means that any differences in the criminal justice responses presented in the next sections are more likely attributable to the changes to the criminal justice response rather than changes to the nature of the background characteristics of the accused and victims.

\section{B. CRIMINAL BACKGROUND AND INCIDENT CHARACTERISTICS}

This section documents the characteristics of the first incident recorded in the database, such as the use of alcohol or other substances at the time of the offence, weapon use, and any prior criminal justice involvement.

With respect to prior convictions for any criminal charges in the justice system (see Table 10), there was limited data on the accused in the baseline time period so no statistical analysis to compare developmental court phases was undertaken. Nevertheless, more than half of the accused overall (53.1 percent or 2,336 of 4,402 of the files where this information was documented) had such a record, whereas a little fewer than half did not. Interestingly, by inspection, there is a difference in the proportion of cases with prior convictions during the docket court-only phase compared to the full DV court phase, such that fewer cases in the later phase involved accused persons with prior convictions. One might question whether this reflects a difference in the specialized court phases with fewer repeat offences. The data on new charges (to be discussed later) will provide more information on whether this is the case.

31 Peter G Jaffe, Claire V Crooks \& David A Wolfe, "Legal and Policy Responses to Children Exposed to Domestic Violence: The Need to Evaluate Intended and Unintended Consequences” (2003) 6:3 Clinical Child and Family Psychology Review 205. 
Table 10: Prior Convictions by Court Development Phase

\begin{tabular}{|l|l|l|l|l|}
\hline Prior Convictions & Baseline & DV Docket & Full DV Court & Total \\
\hline No prior convictions & $45(22.5 \%)$ & $1372(44.5 \%)$ & $649(57.9 \%)$ & $2066(46.9 \%)$ \\
\hline Any prior convictions & $155(77.5 \%)$ & $1710(55.5 \%)$ & $471(42.1 \%)$ & $2336(53.1 \%)$ \\
\hline Total & 200 & 3082 & 1120 & 4402 \\
\hline
\end{tabular}

Table 11: Prior Criminal Convictions of Accused by Court Development Phase

\begin{tabular}{|l|l|l|l|l|}
\hline Prior Criminal Convictions & Baseline & DV Docket & Full DV Court & Total \\
\hline Assault convictions & $56(42.5 \%)$ & $340(20.1 \%)$ & $169(37.0 \%)$ & $565(24.8 \%)$ \\
\hline Domestic assaults & $12(9.1 \%)$ & $115(6.8 \%)$ & $39(8.5 \%)$ & $166(7.3 \%)$ \\
\hline General assaults & $43(32.6 \%)$ & $210(12.4 \%)$ & $121(26.5 \%)$ & $374(16.4 \%)$ \\
\hline Sexual assault & $1(0.8 \%)$ & $14(0.8 \%)$ & $9(2.0 \%)$ & $24(1.1 \%)$ \\
\hline Child abuse & $0(0 \%)$ & $1(0.1 \%)$ & $0(0 \%)$ & $1(0.0 \%)$ \\
\hline Charges other than assault & $71(53.8 \%)$ & $1185(70.2 \%)$ & $253(55.4 \%)$ & $1509(66.2 \%)$ \\
\hline Prior record but no specifics & $5(3.8 \%)$ & $164(9.7 \%)$ & $35(7.7 \%)$ & $204(9.0 \%)$ \\
\hline Total & 132 & 1689 & 457 & 2278 \\
\hline
\end{tabular}

The data in Table 11 indicate the type of prior conviction (when known) for any other criminal offences. Again, because of the limited data collected in the baseline period with respect to this variable, a statistical analysis would not be meaningful. Notably, however, only about one-quarter of the prior convictions across developmental phases were assault convictions of any type.

In the next set of tables, the characteristics of the first incident for each accused are provided to portray the nature of the situations to which the police responded by laying criminal charges. Table 12 identifies who reported the incident to the police. The vast majority of incidents were reported by the victims. Interestingly, the accused reported the incident in about 4 percent of cases across court developmental phases.

Table 12: Who Reported Incident to the Police by Court Developmental Phase

\begin{tabular}{|l|l|l|l|l|}
\hline Who Reported & Baseline & DV Docket & Full DV Court & Totals \\
\hline Victim & $1033(92.3 \%)^{* * * 32}$ & $1862(69.3 \%)^{* *}$ & $725(69.6 \%)$ & $3620(74.7 \%)$ \\
\hline Accused & $30(5.3 \%)^{*}$ & $122(4.5 \%)$ & $38(3.6 \%)$ & $190(3.9 \%)$ \\
\hline Other & $56(5 \%)^{* * *}$ & $704(26.2 \%)^{* * *}$ & $279(26.8 \%)^{* * *}$ & $1039(21.4 \%)$ \\
\hline Total & 1119 & 2688 & 1042 & 4849 \\
\hline \multicolumn{2}{|l|}{ Pearson's chi-square $=251, \mathrm{p}=.000 ;$ Cramer's V = .165 (a “small”33 effect) } \\
\hline
\end{tabular}

32 Stars represent significant differences between categories based on standardized residuals (contact the first author for these differences).

33 Although this is a small effect, it is still important since we are using the most conservative interpretations of the statistical results. 
The statistical analysis indicates some differences in who reported the incident over the court development phases. The most obvious difference is that victims reported more often in the baseline period and "others" (including children, neighbours, bypassers, friends, social workers, and so on) reported more often once the specialized courts were implemented. This might reflect the fact that, with the media attention to domestic violence that accompanied the implementation of the specialized courts, the general public may have become more aware of the serious nature of the issue and the importance of reporting concerns to the police.

Calgary police officers are asked to assess the presence of alcohol at the scene (see Table 13). The differences are statistically significant but present a "small" effect over the court development phases. The major difference is in the DV docket phase wherein the officers less often reported "no alcohol use by either party" and more often noted "alcohol use by the accused but not or no information about the victim." Since the assessment of alcohol use is subjective and not directly relevant to criminal charges, this variable should be interpreted cautiously. What is worth noting is that, across court developmental phases, the accused was much more likely to have been seen as under the influence of alcohol than the victim.

Table 13: Alcohol Present by Court Development Phase

\begin{tabular}{|l|l|l|l|l|}
\hline Alcohol/Drugs Present & Baseline & DV Docket & Full DV Court & Total \\
\hline Not present in either & $525(34.2 \%)^{* * *}$ & $419(22.6 \%)^{* * *}$ & $381(34.4 \%)^{* * *}$ & $1325(29.5 \%)$ \\
\hline $\begin{array}{l}\text { Present in both victim and } \\
\text { accused }\end{array}$ & $360(23.5 \%)$ & $493(26.6 \%)$ & $279(25.2 \%)$ & $1132(25.2 \%)$ \\
\hline $\begin{array}{l}\text { Present in accused but not } \\
\text { victim/no info re victim }\end{array}$ & $438(28.6 \%)^{* * *}$ & $821(44.3 \%)^{* * *}$ & $351(31.7 \%)^{*}$ & $1610(35.8 \%)$ \\
\hline $\begin{array}{l}\text { Present in victim but not } \\
\text { accused/no info re accused }\end{array}$ & $41(2.7 \%)$ & $66(3.6 \%)$ & $28(2.5 \%)$ & $135(3 \%)$ \\
\hline Other ${ }^{34}$ & $169(11 \%)^{* * *}$ & $551(3 \%) * * *$ & $67(3.1 \%)$ & $291(6.5 \%)$ \\
\hline Total & 1533 & 1854 & 1106 & 4493 \\
\hline Pearson's chi-square $=207, \mathrm{p}>.000 ;$ Cramer's V V.15 (a small effect) & & \\
\hline
\end{tabular}

As can be seen in Table 14, in the majority of cases, no weapons were used. There were no important differences in weapon use across the court developmental phases.

34 “Other" includes circumstances such as where alcohol was present in the environment. 
Table 14: Weapon Use by Court Development Phase

\begin{tabular}{|l|l|l|l|l|}
\hline Type of Weapon Used & Baseline & DV Docket & Full DV Court & Total \\
\hline No weapon used to injure & $1394(90.5 \%)$ & $2766(86.3 \%)$ & $1003(81.9 \%)$ & $5163(86.5 \%)$ \\
\hline Used knife & $52(3.4 \%)$ & $93(2.9 \%)$ & $53(4.3 \%)$ & $198(3.3 \%)$ \\
\hline Used firearm & $5(0.3 \%)$ & $4(0.1 \%)$ & $2(0.2 \%)$ & $11(0.2 \%)$ \\
\hline Used other object & $90(5.8 \%)$ & $341(10.6 \%)$ & $168(13.7 \%)$ & $599(10 \%)$ \\
\hline Total & 1541 & 3204 & 1226 & 5971 \\
\hline Pearson's chi-square $=58.3, \mathrm{p}=.000$; Cramer's V $=.07$ (a negligible effect) \\
\hline
\end{tabular}

Table 15 displays the most serious police charges with respect to the incident by court developmental phase. The most frequently occurring charge by police officers was common assault for about two-thirds of the charges. Common assaults, assaults with a weapon, and aggravated assaults together accounted for 78.6 percent of charges. However, any differences across the court development phases are negligible.

Table 15: Most Serious Police Charge by Court Developmental Phase

\begin{tabular}{|l|l|l|l|l|}
\hline Charge & Baseline & DV Docket & $\begin{array}{l}\text { Full DV } \\
\text { Court }\end{array}$ & Total \\
\hline Common assault & $1070(64.5 \%)$ & $2217(67.1 \%)$ & $952(67.3 \%)$ & $\begin{array}{l}4239 \\
(66.5 \%)\end{array}$ \\
\hline Assault with a weapon & $189(11.4 \%)$ & $359(10.9 \%)$ & $184(13.0 \%)$ & $732(11.5 \%)$ \\
\hline $\begin{array}{l}\text { Aggravated assault/assault causing } \\
\text { bodily harm }\end{array}$ & $7(0.4 \%)$ & $22(0.7 \%)$ & $7(0.5 \%)$ & $36(0.6 \%)$ \\
\hline Uttering threats & $125(7.5 \%)$ & $254(7.7 \%)$ & $102(7.2 \%)$ & $481(7.5 \%)$ \\
\hline Mischief/causing disturbance & $59(3.6 \%)$ & $128(3.9 \%)$ & $50(3.5 \%)$ & $237(3.7 \%)$ \\
\hline Criminal harassment/harassing calls & $23(1.4 \%)$ & $84(2.5 \%)$ & $16(1.1 \%)$ & $123(1.9 \%)$ \\
\hline Breaches of court orders/probation & $11(0.7 \%)$ & $55(1.7 \%)$ & $18(1.3 \%)$ & $84(1.3 \%)$ \\
\hline Sexual assaults/aggravated/threats & $33(2.0 \%)$ & $23(0.7 \%)$ & $4(0.3 \%)$ & $60(0.9 \%)$ \\
\hline Weapons offences & $5(0.3 \%)$ & $23(0.7 \%)$ & $11(0.8 \%)$ & $39(0.6 \%)$ \\
\hline Break \& enter related & $24(1.4 \%)$ & $66(2.0 \%)$ & $26(1.8 \%)$ & $116(1.8 \%)$ \\
\hline Murder (first or second degree) & $5(0.3 \%)$ & $0(0 \%)$ & $0(0 \%)$ & $5(0.1 \%)$ \\
\hline Attempted murder & $1(0.1 \%)$ & $0(0 \%)$ & $3(0.2 \%)$ & $4(0.1 \%)$ \\
\hline Other & $107(6.4 \%)$ & $74(2.2 \%)$ & $42(3.0 \%)$ & $223(3.5 \%)$ \\
\hline Total & 1659 & 3305 & 1415 & 6379 \\
\hline Pearson's chi-square $=141.7, p<.000 ;$ Cramer's V .10 (a negligible effect) & & \\
\hline
\end{tabular}

As can be seen in Table 16, of the total cases, 7.1 percent overall indicate dual charges in which more than one suspect was charged, typically both members of a couple in cases of domestic assault. Although the differences are not statistically significant, the proportion of dual charges in the full DV court phase was reduced. 
Table 16: Dual Charges by Court Development Phase

\begin{tabular}{|l|l|l|l|l|}
\hline Dual Charges & Baseline & DV Docket & Full DV Court & Total \\
\hline No dual charges & $1536(93.7 \%)$ & $3022(91.5 \%)$ & $1355(95.2 \%)$ & $5913(92.9 \%)$ \\
\hline Dual charges & $103(6.3 \%)$ & $279(8.5 \%)$ & $68(4.8 \%)$ & $450(7.1 \%)$ \\
\hline Total & 1639 & 3301 & 1423 & 6363 \\
\hline Pearson's chi-square $=22.5, \mathrm{p}<.000 ;$ Cramer's V $=.06$ (a negligible effect) \\
\hline
\end{tabular}

To summarize this section comparing the criminal background and incident characteristics across the three court developmental phases, similar to the comparison of demographics, there were only two statistically significant differences across the three time periods: at baseline, a higher proportion of victims reported the incidents to the police and differences in the rating of alcohol use by accused and victims, which is subject to the assessment or attention paid by the police officers. The general lack of differences can be interpreted as meaning that any significant changes in the criminal justice responses presented in the next sections can be seen as related to the court processes and not to differences in the nature of the crimes or criminal background characteristics of the accused.

\section{Resolutions in The Docket AND Trial Courts}

This section presents the resolutions of cases, first with respect to cases in the docket court and then cases that continued after the docket court, including going to trial.

First, with respect to the outcomes of cases appearing in the first appearance (docket) court (see Table 17), the most common dispositions across court development phases were a not guilty plea (41.5 percent) and a peace bond (25.8 percent or a little more than onequarter of cases). As mentioned previously, in Calgary's specialized DV courts, peace bonds may be offered to low risk accused who do not have a criminal record or have a minor unrelated criminal record and have expressed a willingness to take responsibility for the incident. This disposition also takes into consideration the wishes of the victim. The conditions of the peace bond usually entail being mandated to conditions such as offender treatment and substance abuse interventions.

Table 17: Resolution in Docket Court by Court Developmental Phase

\begin{tabular}{|l|l|l|l|l|}
\hline Docket Court Resolution & Baseline & DV Docket & Full DV Court & Total \\
\hline Guilty plea & $341(20.5 \%)$ & $676(20.6 \%)$ & $293(20.6 \%)$ & $1310(20.6 \%)$ \\
\hline Peace bond & $134^{* * *}(8.1 \%)$ & $1059 * * *(32.3 \%)$ & $451^{* * *}(31.7 \%)$ & $1644(25.8 \%)$ \\
\hline Not guilty plea & $952^{* * *}(57.3 \%)$ & $1236^{* * *}(37.7 \%)$ & $455^{* * *}(32.0 \%)$ & $2643(41.5 \%)$ \\
\hline Withdrawn & $165^{*}(9.9 \%)$ & $169^{* * *}(5.1 \%)$ & $202^{* * *}(14.2 \%)$ & $536(8.4 \%)$ \\
\hline $\begin{array}{l}\text { Stay of proceedings/ } \\
\text { dismissed for want of } \\
\text { prosecution }\end{array}$ & $55^{* * *}(3.3 \%)$ & $28^{*}(0.9 \%)$ & $8 *(0.6 \%)$ & $91(1.4 \%)$ \\
\hline Other & & & & $140(2.2 \%)$ \\
\hline Total & $13^{* * *}(0.8 \%)$ & $114 * * *(3.4 \%)$ & $13^{* * *}(0.9 \%)$ & 1422 \\
\hline Pearson's chi-square $=626.4, \mathrm{p}<.000 ;$ Cramer’s V .22 (a “moderate” effect) & 6364 \\
\hline
\end{tabular}


Other dispositions or circumstances in docket court include withdrawals, stays of proceedings, and dismissals for want of prosecution. Occurrences such as the accused being deceased, stays for counseling and issuance of warrants are included in the "Other" category. A further almost one-fifth (20.6 percent) of the docket court cases are concluded with a guilty plea across court developmental phases.

The statistical analysis identified significant differences in the dispositions in docket court based on the court developmental phase. The major differences are in the number of peace bonds (with the baseline cases being much lower) and the number of "not guilty" pleas (being much higher at baseline). The number of guilty pleas stayed approximately the same over time. These differences are congruent with the introduction of the specialized DV docket court and illustrate that this shift has been maintained with the addition of the DV trial court.

Probation officers remain involved with accused who received a peace bond at docket court, which means that the conditions of the peace bond are closely attended to. For example, if an individual sent to domestic violence treatment as a condition of the peace bond were to stop attending, the probation officers would be immediately informed and the individual given consequences such as being charged with a breach of the peace bond. ${ }^{35}$ The peace bond and probation conditions from the docket court are, therefore, of interest in the current evaluation. Notably, these conditions were also often imposed on individuals who pled guilty or entered an early case resolution process and were sentenced to a period of probation.

The next table documents the details of the outcomes of cases that were not resolved at docket court (see Table 18).

Table 18: Resolutions at Trial by Court Development Phase

\begin{tabular}{|l|l|l|l|l|}
\hline Resolution & Baseline & DV Docket & Full DV Court & Total \\
\hline Guilty plea & $258(27.2 \%)$ & $260(23.8 \%)$ & $155^{*}(31.1 \%)$ & $673(26.5 \%)$ \\
\hline Peace bond & $169(17.8 \%)$ & $209(19.1 \%)$ & $84(16.8 \%)$ & $462(18.2 \%)$ \\
\hline Trial found guilty & $90(9.5 \%)$ & $100(9.1 \%)$ & $23^{* *}(4.6 \%)$ & $213(8.4 \%)$ \\
\hline Trial found not guilty & $65^{*}(6.9 \%)$ & $55(5.0 \%)$ & $11^{* *}(2.2 \%)$ & $131(5.2 \%)$ \\
\hline $\begin{array}{l}\text { Dismissed for want of } \\
\text { prosecution/ stay of } \\
\text { proceedings }\end{array}$ & $205(21.6 \%)$ & $342^{* * *}(31.3 \%)$ & $46^{* * *}(9.2 \%)$ & $593(23.3 \%)$ \\
\hline Withdrawn & $156(16.5 \%)$ & $124^{* * *}(11.3 \%)$ & $180^{* * *}(36.1 \%)$ & $460(18.1 \%)$ \\
\hline Other & $5(0.5 \%)$ & $3(0.3 \%)$ & $0(0 \%)$ & $8(0.3 \%)$ \\
\hline Total & 948 & 1092 & 499 & 2540 \\
\hline Pearson's chi-square $=226.9, \mathrm{p}<.000 ;$ Cramer's V .21 (a moderate effect) & \\
\hline
\end{tabular}

As is common in the criminal justice system, most cases were dealt with before reaching trial: a little over one-fifth of the cases were dismissed for want of prosecution or a stay of 
proceedings and an almost equal number (slightly less than one-fifth) were withdrawn (18.1 percent) for a total of 41.4 percent of cases. Another just less than one-fifth had peace bonds applied (18.2 percent). A final quarter of the total comprised cases in which the accused changed their plea to guilty between the time of appearances in docket and trial court (26.5 percent).

The first significant difference reflected in Table 18 was that more cases were resolved with a guilty plea at trial in the full DV court phase. The most significant differences were with respect to the proportions of cases in the "stay/dismissed" categories and the withdrawn category. Notably, though, it was often difficult to ascertain into which of these three categories a case fit, since the exact nature of the case was not necessarily noted in the Crown file. A reanalysis combining stays, dismissed, and withdrawn cases resulted in a significant Pearson's chi-square of $40.3(\mathrm{p}<.000)$ but a negligible Cramer's V of .09. As such, the difference between the withdrawals, stays, and dismissed charges across phases should not be considered important.

Across the three time periods, only 13.6 percent (344) of the 2,539 cases that proceeded after the first appearance court were actually tried in court, of which almost two-thirds (61.9 percent) were found guilty across court developmental phases, as can be seen in Table 19 . Although the differences are not statistically significant, the proportion of successfully tried cases has increased over time.

Table 19: Trial Outcomes Across Court Developmental Phases

\begin{tabular}{|l|l|l|l|l|}
\hline Resolution & Baseline & DV Docket & Full DV Court & Total \\
\hline Trial found guilty & $90(58.1 \%)$ & $100(64.5 \%)$ & $23(67.6 \%)$ & $213(61.9 \%)$ \\
\hline Trial found not guilty & $65(41.9 \%)$ & $55(35.3 \%)$ & $11(32.4 \%)$ & $131(38.1 \%)$ \\
\hline Total & 155 & 155 & 34 & 344 \\
\hline Pearson's chi-square $=1.9, \mathrm{p}=.38$ (not significant) & \\
\hline
\end{tabular}

What happened once cases reached trial did not change substantially across the court developmental phases. The major differences are that a large proportion of cases were dealt with at docket court and fewer cases proceeded to trial, meaning that the cases that were actually tried could receive more attention. It is important to note, again, that the data for the "Full DV Court" reflect the court's transition to a fully specialized trial court. As such, it will be important to continue to monitor the trial court dispositions from 2008 on, as this is when the key players see the trial court as more accurately described as fully specialized.

Another variable of interest was the extent to which the victims appeared at trial. As can be seen in Table 20, there was a statistically significant shift after the specialized trial court was introduced such that more victims appeared at trial. Notably, it was not until the opening of the specialized domestic violence trial court that HomeFront court caseworkers had the formal mandate to work with victims through to trial. 
Table 20: Did Victim Appear at Trial by Court Developmental Phase

\begin{tabular}{|l|l|l|l|l|}
\hline & Baseline & DV Docket & Full DV Court & Total \\
\hline No & $59(79.7 \%)$ & $407^{*}(74.4 \%)$ & $179^{* *}(50.7 \%)$ & $645(66.2 \%)$ \\
\hline Yes & $15^{*}(20.3 \%)$ & $140^{* *}(25.6 \%)$ & $174^{* * *}(49.3 \%)$ & $329(33.8 \%)$ \\
\hline Total & 74 & 547 & 353 & 974 \\
\hline \multicolumn{4}{|l}{ Pearson's chi-square $=60.4, \mathrm{p}<.000$; Cramer's V $=.25$ (a moderately strong effect) } \\
\hline
\end{tabular}

To summarize and interpret the two previous sections on resolutions at docket court compared to cases that proceeded to trial, one gross measure of whether the specialization has resulted in changes to the criminal justice response to domestic violence is simply a comparison of how many cases were resolved without the need for a trial. This data is presented in Table 21.

The category "Concluded at docket" includes all cases resolved with a guilty plea, peace bond, or early case resolution in addition to cases withdrawn at docket. Similarly, the category "Concluded at trial” includes cases with guilty or not guilty resolutions, guilty pleas, and cases withdrawn and dismissed for want of prosecution at trial. The "Other" category includes cases where the accused was deceased or where a warrant was issued.

Table 21: Cases Resolved at Docket versus Trial Across Court Developmental Phases

\begin{tabular}{|l|l|l|l|l|}
\hline Case Resolution & Baseline & DV Docket & Full DV Court & Total \\
\hline Concluded at docket & $706^{* * *}(42.6 \%)$ & $2303^{* * *}(70.2 \%)$ & $966(67.9 \%)^{*}$ & $3975(62.5 \%)$ \\
\hline Concluded at trial & $944^{* * *}(56.9 \%)$ & $962^{* * *}(29.3 \%)$ & $454 * * *(31.9 \%)$ & $2360(37.1 \%)$ \\
\hline Other & $9(0.5 \%)$ & $14(0.4 \%)$ & $2(0.1 \%)$ & $25(0.4 \%)$ \\
\hline Total & 1659 & 3279 & 1422 & 6360 \\
\hline \multicolumn{2}{|l|}{ Pearson's chi-square $=385.8, p>.000 ;$ Cramer's V =.17 (a “small” effect) } \\
\hline
\end{tabular}

The analysis shows that significantly more cases concluded before trial after the introduction of the specialized docket court, a change that was maintained with the specialized trial court. At baseline, less than half (43 percent) of cases were concluded at this early stage; after the introduction of the specialized docket court almost 70 percent of cases were concluded at docket, a proportion that was maintained with the introduction of the specialized domestic violence trial court with two-thirds (68 percent) concluded at docket.

The data set captured up to eight charges for some offenders. As is the case across jurisdictions, not all charges were addressed at trial. For example, some were dismissed and some were stayed. To capture the outcomes for the accused, the most serious dispositions across charges for the first incident are provided in Table 22. Note that these dispositions are only applicable to cases where the accused pled guilty, was found guilty, or accepted a peace bond. The proportion of cases that were withdrawn is noted in the final line of the table for interest. Because of the high number of possible dispositions, a statistical analysis was not conducted. 
Table 22: Most Serious Disposition from Trial by Court Phase

\begin{tabular}{|l|l|l|l|l|}
\hline Disposition & Baseline & DV Docket & Full DV Court & Total \\
\hline Peace bond & $160(32.4 \%)$ & $192(39.8 \%)$ & $84(37.5 \%)$ & $436(36.3 \%)$ \\
\hline Suspended sentence & $111(22.5 \%)$ & $54(11.2 \%)$ & $55(24.6 \%)$ & $220(18.3 \%)$ \\
\hline Supervised probation & $50(10.1 \%)$ & $112(23.2 \%)$ & $26(11.6 \%)$ & $188(15.7 \%)$ \\
\hline Incarceration & $78(15.8 \%)$ & $36(7.5 \%)$ & $37(16.5 \%)$ & $151(12.6 \%)$ \\
\hline Fine & $60(12.1 \%)$ & $33(6.8 \%)$ & $13(5.8 \%)$ & $106(8.8 \%)$ \\
\hline Conditional discharge & $20(4.0 \%)$ & $23(4.8 \%)$ & $7(3.1 \%)$ & $50(4.2 \%)$ \\
\hline Intermittent sentence & $1(0.2 \%)$ & $5(1 \%)$ & $0(0 \%)$ & $6(0.5 \%)$ \\
\hline Absolute discharge & $8(1.6 \%)$ & $2(0.4 \%)$ & $0(0 \%)$ & $10(0.8 \%)$ \\
\hline Time in custody & $1(0.2 \%)$ & $18(3.7 \%)$ & $0(0 \%)$ & $19(1.6 \%)$ \\
\hline Firearms prohibitions & $3(0.6 \%)$ & $2(0.4 \%)$ & $1(0.4 \%)$ & $6(0.5 \%)$ \\
\hline Intermittent sentences & $1(0.2 \%)$ & $5(1.0 \%)$ & $0(0 \%)$ & $6(0.5 \%)$ \\
\hline Restitution & $2(0.4 \%)$ & $4(0.8 \%)$ & $0(0 \%)$ & $6(0.5 \%)$ \\
\hline Unsupervised probation & $0(0 \%)$ & $1(0.2 \%)$ & $1(0.4 \%)$ & $2(0.2 \%)$ \\
\hline Total & 494 & 482 & 224 & 1200 \\
\hline $\begin{array}{l}\text { Withdrawn/Stay/Dismissed for } \\
\text { want (not in total) }\end{array}$ & $358 / 852$ cases & $395 / 877$ cases & $205 / 429$ cases & $958 / 2158$ cases \\
& $(42 \%)$ & $(45 \%)$ & $(37.8 \%)$ & $(44.4 \%)$ \\
\hline
\end{tabular}

\section{ESTIMATES OF NEW CHARGES/RECIDIVISM}

Recidivism is one of the major indicators that a specialized justice approach to domestic violence is more effective than non-specialization. ${ }^{36}$ Police records of new charges are the most commonly collected criminal justice data to measure recidivism. Of the research reviewed on specialized domestic violence courts, the majority used records of new charges to determine recidivism rates, regardless of whether the offender was convicted of the offence or not. ${ }^{37}$ Typically, recidivism in the published research is calculated from the date of conviction until the date of the next incident when charges are laid. Recidivism in the current study includes both additional criminal charges for domestic violence and breached court or civil orders related to domestic violence.

Samantha Moore, Two Decades of Specialized Domestic Violence Courts: A Review of the Literature (New York: Center for Court Innovation, 2009) at 7, online: Center for Court Innovation <http://www. courtinnovation.org/research/two-decades-specialized-domestic-violence-courts-review-literature>.

Eve Buzawa et al, Response to Domestic Violence in a Pro-Active Court Setting: Final Report (Washington, DC: US Department of Justice, National Institute of Justice, 1999), online: National Criminal Justice Reference Service <https://www.ncjrs.gov/pdffiles1/nij/grants/181427.pdf>; Robert C Davis, Barbarba E Smith \& Caitlin R Rabbit, "Increasing Convictions in Domestic Violence Cases: A Field Test in Milwaukee” (2001) 22:1 The Justice System Journal 61; Gover, MacDonald \& Alpert, supra note 19; Adele Harrell et al, Final Report on the Evaluation of the Judicial Oversight Demonstration, Volume 1: The Impact of JOD in Dorchester and Washtenaw County (Washington, DC: US Department of Justice, 2007), online: National Criminal Justice Reference Service <http://www. ncjrs.gov/pdffiles1/nij/219382.pdf>; Hoffart \& Clarke, supra note 12; Hornick et al, supra note 17; Newmark et al, supra note 22; Tutty, McNichol \& Christensen, supra note 16; Ursel \& Hagyard, supra note 14; Christy A Visher et al, "Reducing Intimate Partner Violence: An Evaluation of A Comprehensive Justice System-Community Collaboration” (2008) 7:4 Criminology and Public Policy 495. 
It was interesting to look at the period between when the first incident was resolved in court and when any recidivism occurred. As can be seen in Table 23, 75 percent of any recidivism occurred in the first year.

Table 23: Time of New DV Charges/Breaches after the First Incident

\begin{tabular}{|l|l|l|l|l|}
\hline $\begin{array}{l}\text { Time of New DV } \\
\text { Charges }\end{array}$ & Baseline & DV Docket & Full DV Court & Total \\
\hline Within 6 months & $141(45.8 \%)$ & $361(54.2 \%)$ & $246(67 \%)$ & $748(55.8 \%)$ \\
\hline 6 months to 1 year & $46(14.9 \%)$ & $147(22.1 \%)$ & $75(20.4 \%)$ & $268(20 \%)$ \\
\hline 1 to 2 years & $35(11.4 \%)$ & $98(14.7 \%)$ & $39(10.6 \%)$ & $172(12.8 \%)$ \\
\hline 2 to 5 years & $43(14.0 \%)$ & $56(8.4 \%)$ & $7(1.9 \%)$ & $106(7.9 \%)$ \\
\hline After 5 years & $43(14.0 \%)$ & $4(0.6 \%)$ & $0(0 \%)$ & $47(3.5 \%)$ \\
\hline Total & 308 & 666 & 367 & 1341 \\
\hline
\end{tabular}

The statistical comparison of whether any new domestic violence related charges or breaches of orders (after the first incident recorded) occurred over court development phases was statistically significant. As can be seen in Table 24, the highest rate of new charges and breaches within two years was at baseline (33.9 percent), followed by the full DV court phase (26 percent), and with the smallest proportion of new charges and breaches during the introduction of the specialized docket court (18.9 percent).

Hoffart and Clarke's 2004 evaluation of the Calgary DV court compared their larger baseline sample (with over 2,000 cases from January 1998 to April 1999) to a slightly smaller time period for the docket court cases (from between May 1, 2001 and December 31, 2003) whereas the current evaluation used cases from 2001 to 2004. With these considerations in mind, any differing rates are not surprising. Their data on any new charges and breaches within two years was 38.8 percent at baseline compared to 21.1 percent at specialized docket court; it is not identical, but, it is similar to our results. To summarize, major decreases in new cases and breaches occurred after baseline and were maintained with the introduction of the specialized full DV court.

Table 24: New DV Charges/Breaches within 2 years by Court Development Phase

\begin{tabular}{|l|l|l|l|l|}
\hline Type of Recidivism & Baseline & DV Docket & $\begin{array}{l}\text { Full DV } \\
\text { Court }\end{array}$ & Total \\
\hline New charges/breaches & $534 * * *(33.9 \%)$ & $616^{* * *}(18.9 \%)$ & $368(26.0 \%)$ & $1598(24.3 \%)$ \\
\hline No new charges/breaches & $1043^{* * *}(66.1 \%)$ & $2643^{* * *}(81.1 \%)$ & $1050(74.0 \%)$ & $4736(75.7 \%)$ \\
\hline Total & 1577 & 3259 & 1418 & 6254 \\
\hline Pearson's chi-square $=132.2, \mathrm{p}<.000 ;$ Cramer's V $=.15$ (a “small” effect) \\
\hline
\end{tabular}

The type of new incident (where documented) is presented in Table 25. There was a statistically significant difference across time that indicates a "small" effect, such that more recidivism was in the form of breaches of orders in the DV court specialization phases (both DV docket and full DV court). At baseline, more had been charged with new criminal charges and fewer were charged with both breaches and criminal charges. 
Table 25: Type of New Incident within 2 years by Court Development Phase

\begin{tabular}{|l|l|l|l|l|}
\hline Type of New Incident & Baseline & DV Docket & Full DV Court & Total \\
\hline Breaches of orders & $185^{* *}(35.2 \%)$ & $294(47.7 \%)$ & $193^{*}(52.9 \%)$ & $672(44.6 \%)$ \\
\hline New criminal charges & $86(16.3 \%)$ & $149^{*}(24.2 \%)$ & $64(17.5 \%)$ & $299(19.8 \%)$ \\
\hline Both & $255^{* * *}(48.5 \%)$ & $173^{* *}(28.1 \%)$ & $108(29.6 \%)$ & $536(35.6 \%)$ \\
\hline Total & 616 & 365 & 1507 \\
\hline Pearson's chi-square $=65.5, \mathrm{p}<.000 ;$ Cramer's V $=.15$ (a “small” effect) \\
\hline
\end{tabular}

As can be seen in Table 25, the nature of the proportions of new charges and breaches changed such that, by the specialized DV docket court phase, the most common form of recidivism was breaches of orders, with fewer individuals receiving new criminal charges or both new criminal charges and breaches of orders, a pattern that was maintained with the introduction of the DV specialized trial court process.

Further, fewer cases of both breaches and new charges were noted for both the specialized DV court phases as compared to baseline. Although a slightly higher proportion of new charges and breaches were dealt with in the specialized DV trial phase, the nature of the new charges was different from baseline because they were breaches rather than new criminal charges. A more effective court system could result in a greater number of breaches, suggesting that the new domestic violence court may have succeeded in implementing more diligent monitoring and supervision of offenders. ${ }^{38}$

\section{E. Analysis}

This section summarizes the core results of the quantitative data across the court developmental phases. Firstly, the characteristics of the victims and the accused were relatively stable across the three time periods. The only significant comparison of the criminal justice background and incident characteristics is that a higher proportion of victims contacted the police during the baseline period. With respect to dispositions from the docket court, significantly more peace bonds were issued in the specialized docket, a process that was maintained in the full DV court, with the number of baseline cases receiving peace bonds being much lower. Also, the number of "not guilty” pleas was much higher at baseline, resulting in more cases proceeding to trial. Both conclusions are congruent with the intent of the DV specializations under the Calgary model. The peace bond approach remains somewhat controversial, however, as our qualitative data will illustrate.

More cases concluded before trial after the introduction of the specialized docket court, which was maintained with the specialized trial court. At baseline, less than half (43 percent) of cases were concluded at this early stage; after the introduction of the specialized docket court, 70 percent of cases were concluded at docket, a proportion that was maintained with the introduction of the specialized domestic violence trial court, with two-thirds (68 percent) concluded before trial. This is an important change. Cases resolved expeditiously at docket 
court, no matter the resolution, are less expensive in both monetary terms and with respect to the emotional toll on both victims and the accused.

Interestingly, after the specialized trial court was introduced, more victims appeared at trial. This shift is likely the result of the HomeFront court caseworkers extending their support to victim witnesses through to the trial. This is an important development, as it shows an increased engagement with the criminal process on the part of victims, as well as a reduced need to stay or withdraw charges for victim non-appearance.

Regarding recidivism, significantly more breaches were documented for cases that proceeded to the specialized DV courts compared to baseline. The highest rate of new charges and breaches within two years was at baseline, followed by the full DV court, with the smallest proportion of new charges and breaches during the introduction of the specialized docket court. As noted, however, dealing with more breaches may indicate that the police and courts now have more capacity to address these important occurrences through more diligent monitoring and supervision of offenders, especially as fewer cases are being tried.

Further, fewer cases of both breaches and new charges were noted for both the specialized DV court phases as compared to baseline. While it is not possible to know for certain why these differences resulted, one interpretation is that accused have become aware that the criminal justice system, including the courts, perceive spousal assaults more seriously and, as a result, they are not re-offending to the same extent as previously. It is also possible that the batterer treatment programs are having a positive effect, as our results in the next section address. $^{39}$

\section{F. Qualitative Data}

A component of the evaluation of Calgary's specialized DV courts included interviews with men mandated to attend batterer treatment programs ${ }^{40}$ and justice and community stakeholders. ${ }^{41}$ The interviews with mandated men revealed both benefits and challenges of the Calgary DV courts and their approach and provide somewhat of a contrast to the quantitative data. Some men minimized their own behaviours and blamed their partners. Some believed that the system was biased against them in favour of victims. Even so, a number of men had positive comments about the way that their cases had been handled by police and probation services. ${ }^{42}$ Several men mentioned that the police had dealt with previous instances of domestic violence without laying criminal charges, perhaps indicating some under-enforcement of the criminal law.

Julia C Babcock, Charles E Green \& Chet Robie conducted a meta-analysis of 22 studies finding a "small" effect on reducing recidivism in "Does batterers' treatment work? A meta-analytic review of domestic violence treatment” (2004) 23:8 Clinical Psychology Review 1023.

40 Thirty-seven men who attended either Calgary Counselling's Responsible Choices for Men's Groups or the YWCA Sheriff King Home Paths of Change were interviewed.

41 These interviews included 31 stakeholders from the justice and legal community (including individuals from HomeFront (the agency that provides caseworker support and early intervention programs), the Crown's office, the defence bar, and police and probation services), as well as individuals from counseling and treatment, advocacy, and other community agencies.

42 A few men alleged that the police had been verbally and physically aggressive with them, however, and some had issues with their probation officers. 
With respect to their involvement with the Calgary DV courts, a number of the men were confused about the criminal justice system; several did not realize their cases were being dealt with in a specialized court, and there was a lack of understanding about the differences amongst, and the consequences of, various sanctions. All but one of the men completed their batterer treatment programs, and the majority, though concerned about having been forced into treatment, reported having learned some useful skills and having made changes to their behavior as a result. They also had suggestions for how batterer treatment programs could be improved.

The 31 justice and community stakeholders indicated many benefits with Calgary's DV courts. Its streamlined, expedient process, knowledgeable personnel, communication amongst players in the criminal justice system, and continuum of services for victims and offenders were seen to fill gaps in, and improve upon, the previous criminal justice system approach to domestic violence cases. Several concerns and challenges were also raised, however. The DV courts were seen to have struggled to meet the increased volume of cases, leading to delays in case processing times and offsetting one of the potential benefits of a specialized approach. There were also issues identified with respect to buy-in from judges, prosecutors, and defence counsel. Interestingly, in contrast to the quantitative data, many interviewees perceived dual charging as a continuing problem, which was seen to flow from lack of police discretion and expertise. They were also critical about the lack of communication between criminal and civil courts in the family division, leading to conflicting decisions that may have affected victims' safety. A number of interviewees saw the peace bond approach as contentious for being too lenient, and because breaches (including those for failing to attend treatment) were not well enforced. There was a concern about a lack of support in housing and finances that would assist women to leave their partners. Challenges with the provision of batterer treatment were also identified, including the volume and appropriateness of referrals, difficulties treating offenders with mental health issues, and access to treatment for rural offenders. Concerns were also expressed about the ability of the DV courts to serve the needs of marginalized populations - language and cultural barriers for immigrant populations were identified, as well as lack of treatment options for Aboriginal people, persons with disabilities, and members of the lesbian, bisexual, gay, transgender, and queer community.

Recommendations suggested by the stakeholders included ongoing education for justice personnel on domestic violence and its impact on marginalized populations, expanded resources for the DV courts to deal with increased volumes and changing personnel, better supports for victims, and a communication mechanism between civil and criminal courts.

\section{CONCLUSiONS}

A number of benefits were revealed in the current evaluation of Calgary's DV courts. To summarize the major changes, there was a dramatic increase in the use of peace bonds at docket court after DV specialization (as would be expected by the model), which was maintained with the introduction of the specialized trial court. More cases concluded at docket court with the accused taking responsibility for their behaviours via either a guilty plea, peace bond, or an early case resolution (with a guilty plea): 29.4 percent at baseline, 
64.2 percent at DV docket, and 53.2 percent at full DV court. Fewer cases were actually tried after the specialized trial court was enacted.

Overall, the quantitative data show positive outcomes after specialization. The fact that there are essentially two courts, one docket and one trial, allows low risk cases to be processed quickly, while more complex cases requiring more resources are dealt with in the trial court. Another potentially positive outcome of the Calgary DV courts is that the increase in the number of cases concluded without a trial means that fewer victims (and perhaps others such as child witnesses) will be put through the ordeal of testifying. ${ }^{43}$ The increase in victims appearing at those cases that do proceed to trial means fewer stays for want of prosecution, and may indicate an increased willingness of victims to participate in the process, perhaps because of enhanced victim services and supports. This inference must be approached with caution, however, in light of the finding that victims were more likely to report domestic violence to the police before specialization. It is unclear why this shift occurred, and it is an important area for further research.

The decrease in trials in the Calgary DV court may also suggest that more offenders are willing to take the advantages offered by the peace bond model rather than take their chances with sentence following trial. The peace bond approach raises interesting issues concerning offender accountability. ${ }^{44}$ However, the interviews with men mandated to treatment suggested that, even though their criminal charges had been withdrawn, the mandatory attendance at batterer treatment for at least three months, and the ongoing monitoring by probation for one year, imparted upon them that the criminal justice system considered their actions to be serious and requiring considerable societal intervention. Although the men's concerns that they were victims of bias are potentially problematic in light of studies showing that men who feel they have been treated unfairly are more likely to reoffend, ${ }^{45}$ the recidivism data shows positive results. Other interviewees commented positively on the expertise of judges and other justice personnel in the specialized DV court, which is favourable in terms of buy-in.

The reduction in the number of cases with dual charges in the DV courts, although not statistically significant, suggests that police may be paying more attention to determining the primary aggressor rather than strictly following zero tolerance policies. This is not to say that all cases with dual charges reflect an inappropriate application of the policy, but the reduction may still show an improvement in ensuring that appropriate cases are ending up before the courts.

At the same time, it is interesting to note that justice and community stakeholders continue to see dual charging as an issue and, to the extent there may have been an improvement, it may flow from Alberta's adoption of best practices for identifying primary aggressors, which 
is not strictly speaking an aspect of the specialized DV courts. ${ }^{46}$ Additionally, these numbers do not allow us to assess whether under-enforcement of the criminal law remains a problem, since the data only deal with cases that end up before the DV courts. The interviews with men mandated to treatment indicate that under-enforcement may continue to be an issue in some cases. Moreover, whether over- and under-enforcement concerns related to ethnicity, Aboriginality, class, and other indicators of marginalization have been addressed by Calgary's DV courts cannot be assessed from this data, and is an important subject for future research. ${ }^{47}$ The consistency in percentages of racialized litigants between the different phases of the court suggests that no significant changes have occurred in this respect, and the interviews indicated continuing concerns over access to the court by marginalized groups.

Another challenge is that of managing case volumes and the time to disposition in the DV courts, particularly since some of the benefits of fast case processing for victim engagement may be lost if there are serious delays. The lack of information available to the parties about the criminal justice system and its approach to domestic violence, concerns about buy-in and neutrality, and the need for ongoing training and education of justice personnel are also important matters to address. The disconnect and lack of communication between criminal and civil justice systems is a major concern identified in this and other evaluations. ${ }^{48}$ Although there is better collaboration and coordination within the DV court, there remains a lack of coordination amongst courts — criminal and family, and provincial and superior. ${ }^{49}$ There has been no evaluation of Alberta's overall approach to domestic violence through multiple forums (as opposed to evaluations of the individual components), which is another important area for future research.

See Domestic Violence Handbook For Police and Crown Prosecutors in Alberta (Edmonton: Alberta Justice, 2008) at 81-90, online: Alberta Justice <http://justice.alberta.ca/programs_services/families/ Documents/DomesticViolenceHandbook-full.pdf $>$.

47 For literature on over and under enforcement, see supra note 3. Although demographic data was collected for the evaluation, it has not yet been cross-analyzed with case outcome data, which is an important future area of research.

48 See e.g. Leslie Tutty et al, Alberta's Protection Against Family Violence Act: A Summative Evaluation (Calgary: RESOLVE Alberta, 2005).

49 This could be addressed by better communication systems between criminal, civil, and family systems See for example Pamela Young, An Informed Response: An Overview of the Domestic Violence Court Technology Application and Resource Link (New York: Center for Court Innovation, 2001), online: Center for Court Innovation <http://www.courtinnovation.org/pdf/info_response.pdf>, describing the New York Courts' use of technology to coordinate the response to domestic violence (albeit in the criminal sphere alone). Alternatively, legislative reforms could compel judges to avoid inconsistent orders. See e.g. MacDowell, supra note 43 at n 55. A third option is an integrated DV court, where criminal and family matters are heard in a one judge, one family model. See MacDowell, ibid. 